\title{
Full-sibling allelic frequency and sharing among Madurese: STR technique by 12 locus and the sex-typing amelogenin gene
}

Agung Sosiawan ${ }^{1,4^{*}}$, Ahmad Yudianto 2,3,4, Abdul Hadi Furqoni ${ }^{4,5}$, Simon Martin Manyanza Nzilibili, 3,6 and Indah Nuraini ${ }^{4}$

\begin{abstract}
Background: Sibling relation over chosen STR loci and localized database is yet to be developed in Indonesia like into many other countries despite the demand of varied ethnic population, catastrophes and civil conflict that call forensic preparedness. The targeted application includes human genomic typing and profile, kinship/sibship relation, forensic applications, individual identification, and or claneology tracing. Consequently, this study devotes on sibship in assessing and establishing preferable STR loci and allelic sharing extent amongst Madurese full sibling.

Materials and methods: One hundred blood samples were used to examine sibling relationship among 50 full siblings (25 pairs) assigned from a total of 100 individuals of 25 Madura families. Sibship relation was done by STR technique profile by 12 loci (CSF1PO, F13B, FES, TH01, TPOX, VWA, D5S818, D7S820, D8S1179, D13S317, D16S539, and D18S51) and a sex-typing amelogenin gene locus

Results: From 300 observations ( 25 pairs of full-sibling $\times 12$ loci) of genotyped STR allele, of allele sharing, has found 4 STR loci: FES, CSF1PO, F13, and D8S1179 with high-shared allelic frequency in two alleles sharing among twelve STR loci by 52\%, 52\%, 44\%, and 40\% respectively. As for the four main loci of full sibling with one allele sharing, i.e, D75820, D18S51, vWA, and THO1, have a sequence of percentages from large to small as follows: 76\%, 76\%, 72\%, and 60\%, respectively. Furthermore, STR locus WWA expressed null shared allele in 24 allele-sharing category. Likewise, F13 and FES both typed null allele in zero allele-sharing category among these full sibling Conclusion: Through the use of 12 autosomal STR loci, the study has signified the strength of 2 shared allele evidence by $51.2 \%$ in establishing sibship and recommend D7S820, WWA, TH01, and D18S51 as STR loci of choice when typing sibling among Madurese.
\end{abstract}

Keywords: Allele sharing, DNA STR loci, Full sibling, Madurese, Sibship

\section{Main text}

\section{Background}

Short tandem repeats (STRs) loci establishment for individualized population is a tedious and rigorous process. The establishment is significant for a wider purpose including Sibship determination. Despite the fact that genomic

* Correspondence: agung-s@fkg.unair.ac.id

${ }^{1}$ Faculty of Dental Medicine, Universitas Airlangga, J. Mayjend. Prof. Dr. Moestopo 47, Surabaya 60132, Indonesia

${ }^{4}$ Human Genetic and Forensic Laboratory, Institute of Tropical Disease, Universitas Airlangga, Surabaya, Indonesia

Full list of author information is available at the end of the article variation prevails among ethnicities/geographical boundaries, individual locus and population-based establishment STR paramount the accuracy. As learnt in the existing historical differences of STR loci from the very first set of UK by FSS in 1995 to the latest USA CODIS of 2017 based on their local dedicated project, specific loci standout among the many overlapping STR and world-wide shared locus inclusivity (John M Butler 2006; Hares 2012, 2015; J M Butler and Hill 2012; Agrawal and Khan 2005; John M Butler 2015). Determination of STR locus that is inclusive in a nation help not only to database establishment and point of reference but also to a known set of STR core that effectively discriminates a particular population. 


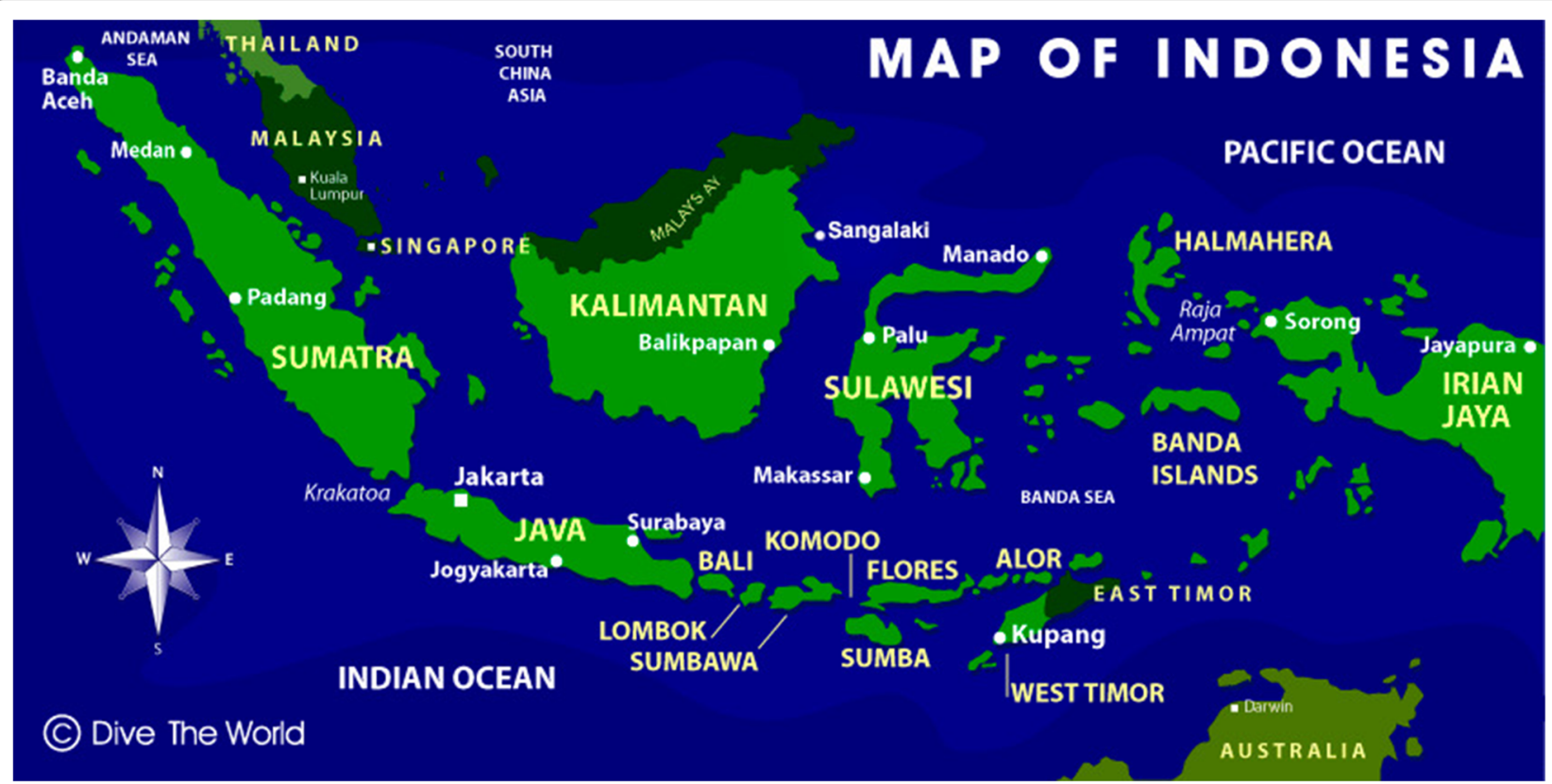

Fig. 1 The map of Indonesia locating the Madura Island (pointed by red arrow) and other geographically isolated islands with bio diversified ethnicities. Retrieved from https://www.dive-the-world.com/maps-indonesia.php

Currently, more than 20,000 STR loci are known as the result of the USA human genetic program that leads to the selection of the 13 STR loci in 1997. This fact, together with identity variability of repeating unit length in STR and allele matching among individuals, propose the likelihood of having significant disparity frequency of different population territories.(United State Department of Homeland Security, 2018) The uniqueness of one population against another suggest a localized and population-based STR derivative however marginalized in number might be against overlapping set voted by other nations (Agrawal and Khan 2005). The practice otherwise is to verify already established and used core sets (i.e., CODIS by FBI) in order to determine the STRs loci with high discrimination power and reference standard to DNA database and profiling inquiries. However, developed forensic laboratories continue to maximize inclusivity for international compatibility, increased discrimination power and reduce mismatched chances in legal summon; exemplified by January 2017 execution of the expanded 20 STR loci (J M Butler and Hill 2012; Hares 2015).

Considering a varied number of application of STR loci; Indonesia, like many other countries, sibling relation over chosen STR loci and localized database is yet developed despite the demand of varied ethnic population and catastrophes that call forensic preparedness, civil, and disasters identification. Also, human genomic typing and profile, kinship relation, forensic applications, and individual identification. Consequently, this study devotes on sibship in assessing allelic relation of a sibling in either identifying the missing person, mixed relatives (brothers/sisters), and or claneology tracing.

This study therefore aims to prompt the establishment of STR loci and allelic sharing extent among Madurese full sibling. The study also proposes a set of preferable STR loci with effective and high matching power of full sibling. The contribution is aided by an allelic frequency of sharing data sheet and graphic presentation among 25 pairs of a full sibling from 25 families.

\section{Materials and methods \\ Population (Madurese-East Java)}

Allele-sharing extent analysis was done on 50 full sibling individuals ( 25 pairs) assigned from a total of 100 individuals obtained from 25 Madura families that originated from madura island can be seen Indonesian map (Fig 1). Inclusion criteria of the volunteer families were three generation pedigree as native Madurese and availability of parents (both father and mother) with their biological children. Then four individuals from every family were assigned in the project: father, mother and two full siblings. Father and mother were included as control/reference for sibling allelic sharing.

\section{Study clearance and subject consent}

Ethical approval to carry out this study is through a clearance number 256/HRECC.FODM/IV/2018 by the Health Research Ethical Clearance Commission of the Faculty of Dental medicine, Universitas Airlangga. All individuals participated in this study consented and 
Table 1 Autosomal STR allelic genotype and amelogenin of the 25 full sibling pairs

\begin{tabular}{|c|c|c|c|c|c|c|c|c|c|c|c|c|c|c|}
\hline \multirow{2}{*}{$\begin{array}{l}\text { F25 family } \\
\text { volunteers }\end{array}$} & \multicolumn{14}{|c|}{ STR locus } \\
\hline & CODE & TPOX & TH01 & D13S317 & D5S818 & D8S1179 & D16S539 & WWA & FES & CSF1PO & F13 & D18S51 & D7S820 & Amelogenin \\
\hline \multirow[t]{4}{*}{1} & $\mathrm{~F} 1$ & 9,10 & 8,10 & 10,11 & 10,12 & 11,13 & 10,11 & 16,17 & 11,12 & 9,11 & 5,5 & 11,12 & 7,9 & 106,112 \\
\hline & M1 & 8,9 & 9,11 & 9,12 & 9,11 & 12,14 & 11,11 & 14,16 & 10,11 & 11,11 & 4,5 & 12,13 & 8,10 & 106 \\
\hline & S & 9,9 & 8,9 & 10,12 & 9,10 & 12,13 & 11,11 & 16,17 & 11,12 & 9,11 & 5,5 & 11,12 & 7,8 & 106,112 \\
\hline & S & 8,10 & 10,11 & 9,11 & 11,12 & 11,12 & 10,11 & 14,16 & 10,11 & 9,11 & 5,5 & 12,13 & 7,10 & 106 \\
\hline \multirow[t]{4}{*}{2} & F2 & 7,9 & 8,9 & 8,10 & 9,11 & 13,13 & 12,13 & 12,14 & 15,16 & 8,10 & 5,5 & 13,14 & 9,11 & 106,112 \\
\hline & M2 & 8,10 & 7,8 & 10,11 & 10,12 & 12,14 & 10,11 & 13,14 & 14,15 & 9,10 & 4,4 & 14,15 & 8,10 & 106 \\
\hline & S & 8,9 & 8,8 & 10,10 & 9,12 & 13,14 & 11,12 & 13,14 & 14,15 & 8,10 & 4,5 & 13,14 & 8,9 & 106,112 \\
\hline & S & 7,8 & 7,8 & 8,10 & 9,10 & 12,13 & 11,13 & 12,14 & 15,16 & 9,10 & 4,5 & 14,14 & 9,10 & 106,112 \\
\hline \multirow[t]{4}{*}{3} & F3 & 9,10 & 10,11 & 11,12 & 11,12 & 12,12 & 15,15 & 15,16 & 14,15 & 10,11 & 4,5 & 16,18 & 10,11 & 106,112 \\
\hline & M3 & 8,9 & 12,13 & 10,11 & 10,12 & 11,13 & 13,14 & 13,14 & 16,17 & 9,10 & 5,5 & 17,19 & 9,10 & 106 \\
\hline & S & 8,10 & 11,12 & 10,12 & 10,11 & 11,12 & 13,15 & 13,15 & 14,16 & 10,10 & 5,5 & 16,17 & 10,10 & 106 \\
\hline & S & 8,9 & 10,13 & 11,12 & 10,11 & 11,12 & 14,15 & 13,16 & 15,16 & 9,11 & 4,5 & 16,19 & 9,10 & 106 \\
\hline \multirow[t]{4}{*}{4} & F4 & 7,10 & 7,9 & 8,8 & 9,11 & 11,13 & 12,13 & 12,14 & 10,11 & 9,11 & 4,5 & 9,10 & 7,8 & 106,112 \\
\hline & M4 & 8,11 & 8,10 & 8,9 & 10,11 & 10,12 & 10,11 & 14,16 & 11,12 & 10,11 & 5,5 & 8,9 & 9,10 & 106 \\
\hline & $S$ & 7,11 & 7,8 & 8,8 & 9,11 & 10,11 & 10,12 & 12,14 & 10,11 & 9,11 & 5,5 & 8,9 & 7,9 & 106 \\
\hline & S & 10,11 & 7,8 & 8,9 & 9,11 & 12,13 & 11,13 & 14,16 & 10,11 & 9,11 & 5,5 & 8,10 & 8,9 & 106,112 \\
\hline \multirow[t]{4}{*}{5} & F5 & 8,11 & 8,9 & 7,8 & 10,12 & 11,12 & 12,12 & 11,13 & 10,11 & 8,10 & 5,5 & 11,12 & 7,8 & 106,112 \\
\hline & M5 & 7,9 & 10,12 & 8,9 & 11,12 & 10,10 & 11,11 & 12,13 & 11,12 & 9,11 & 4,5 & 11,13 & 8,9 & 106 \\
\hline & S & 7,8 & 8,12 & 7,8 & 10,12 & 10,12 & 11,12 & 11,12 & 11,11 & 8,9 & 5,5 & 11,11 & 7,8 & 106 \\
\hline & S & 7,8 & 8,10 & 7,8 & 10,11 & 10,12 & 11,12 & 12,13 & 11,12 & 9,10 & 4,5 & 11,12 & 8,8 & 106,112 \\
\hline \multirow[t]{4}{*}{6} & F6 & 8,10 & 8,10 & 9,11 & 10,13 & 11,11 & 12,13 & 17,19 & 11,11 & 8,10 & 4,5 & 16,18 & 8,9 & 106,112 \\
\hline & M6 & 9,11 & 9,11 & 10,11 & 11.12 & 10,12 & 11,12 & 18,20 & 10,12 & 8,9 & 5,5 & 17,19 & 9,9 & 106 \\
\hline & S & 10,11 & 8,9 & 10,11 & 10,12 & 10,11 & 12,12 & 17,18 & 11,12 & 8,9 & 4,5 & 16,17 & 9,9 & 106 \\
\hline & S & 9,10 & 10,11 & 9,10 & 10,12 & 11,12 & 11.13 & 19,20 & 11,12 & 8,9 & 5,5 & 18,19 & 8,9 & 106 \\
\hline \multirow[t]{4}{*}{7} & F7 & 9,12 & 7,9 & 7,8 & 10,11 & 12,13 & 11,12 & 17,19 & 11,11 & 8,10 & 5,5 & 14,16 & 8,9 & 106,112 \\
\hline & M7 & 9,11 & 8,10 & 8,9 & 9,13 & 10,11 & 10,11 & 18,19 & 10,11 & 9,10 & 5,6 & 15,17 & 9,10 & 106 \\
\hline & S & 9,12 & 7,10 & 7,8 & 9,11 & 10,12 & 10,12 & 19,19 & 11,11 & 8,10 & 5,6 & 14,15 & 9,9 & 106 \\
\hline & S & 9,11 & 7,8 & 7,8 & 11,13 & 10,12 & 10,12 & 18,19 & 10,11 & 8,10 & 5,5 & 16,17 & 8,9 & 106,112 \\
\hline \multirow[t]{4}{*}{8} & F8 & 10,12 & 9,9 & 8,9 & 9,11 & 10,12 & 10,11 & 20,22 & 10,11 & 9,11 & 5,5 & 12,14 & 8,8 & 106,112 \\
\hline & M8 & 9,11 & 8,9 & 8,8 & 10,12 & 9,11 & 11,12 & 19,21 & 11,12 & 8,10 & 4,4 & 11,13 & 9,10 & 106 \\
\hline & S & 9,12 & 8,9 & 8,9 & 10,11 & 10,11 & 10,12 & 19,20 & 10,12 & 9,10 & 4,5 & 11,12 & 8,9 & 106 \\
\hline & S & 9,10 & 9,9 & 8,9 & 10,11 & 10,11 & 11,12 & 20,21 & 10,12 & 9,10 & 4,5 & 12,13 & 8,9 & 106 \\
\hline \multirow[t]{4}{*}{9} & F9 & 6,8 & 11,12 & 8,8 & 10,13 & 13,14 & 11.12 & 17,18 & 11,12 & 8,10 & 5,5 & 16,17 & 9,10 & 106,112 \\
\hline & M9 & 7,9 & 12.12 & 7,8 & 11,12 & 11,12 & 10,11 & 18,18 & 10,11 & 8,11 & 4,5 & 15,17 & 10,11 & 106 \\
\hline & S & 7,8 & 12,12 & 7,8 & 11,13 & 11,13 & 10,11 & 18,18 & 11,12 & 10,11 & 4,5 & 15,16 & 10,11 & 106 \\
\hline & S & 8,9 & 11,12 & 7,8 & 12,13 & 11,13 & 10,12 & 17,18 & 11,12 & 10,11 & 5,5 & 17,17 & 9,10 & 106,112 \\
\hline \multirow[t]{4}{*}{10} & F10 & 9,10 & 7,8 & 8,9 & 10,12 & 12,12 & 11,12 & 14,16 & 11,11 & 9,10 & 5,5 & 15,16 & 8,9 & 106,112 \\
\hline & M10 & 7,8 & 9,10 & 8,8 & 11,13 & 11,13 & 12,13 & 15,17 & 12,12 & 8,9 & 4,4 & 14,15 & 9,9 & 106 \\
\hline & S & 7,9 & 7,9 & 8,9 & 10,13 & 12,13 & 11,13 & 14,15 & 11,12 & 8,9 & 4,5 & 14,15 & 9,9 & 106 \\
\hline & S & 8,9 & 7,10 & 8,8 & 11,12 & 12,13 & 11,12 & 16,17 & 11,12 & 8,10 & 4,5 & 14,16 & 8,9 & 106 \\
\hline \multirow[t]{3}{*}{11} & F11 & 11,13 & 11,12 & 8,9 & 10,11 & 11,13 & 10,11 & 18,20 & 10,12 & 10,10 & 3,4 & 15,17 & 8,9 & 106,112 \\
\hline & M11 & 10,12 & 12,13 & 7,8 & 12,13 & 12,14 & 10,10 & 21,22 & 10,13 & 10,11 & 4,5 & 16,18 & 8,8 & 106 \\
\hline & S & 10,11 & 11,12 & 8,8 & 11,12 & 11,12 & 10,11 & 18,21 & 10,12 & 10,11 & 4,5 & 17,18 & 8,8 & 106 \\
\hline
\end{tabular}


Table 1 Autosomal STR allelic genotype and amelogenin of the 25 full sibling pairs (Continued)

\begin{tabular}{|c|c|c|c|c|c|c|c|c|c|c|c|c|c|c|}
\hline \multirow{2}{*}{$\begin{array}{l}\text { F25 family } \\
\text { volunteers }\end{array}$} & \multicolumn{14}{|c|}{ STR locus } \\
\hline & CODE & TPOX & TH01 & D13S317 & D5S818 & D8S1179 & D16S539 & WA & FES & CSF1PO & F13 & D18S51 & D7S820 & Amelogenin \\
\hline & S & 10,11 & 11.13 & 8,9 & 10,12 & 11,12 & 10,11 & 20,22 & 10,12 & 10,11 & 3,4 & 15,16 & 8,9 & 106 \\
\hline \multirow[t]{4}{*}{12} & $\mathrm{~F} 12$ & 8,10 & 9,11 & 7,8 & 10,13 & 11,12 & 10,10 & 17,19 & 10,12 & 9,10 & 5,5 & 18,19 & 7,8 & 106,112 \\
\hline & M12 & 9,11 & 11,13 & 8,8 & 11,12 & 10,10 & 10,11 & 19,20 & 11,11 & 8,9 & 4,5 & 19,20 & 8,9 & 106 \\
\hline & S & 8,9 & 11,11 & 8,8 & 12,13 & 10,11 & 10,11 & 19,19 & 10,11 & 9,9 & 4,5 & 18,19 & 7,8 & 106 \\
\hline & S & 8,11 & 9,11 & 8,8 & 10,11 & 10,11 & 10,11 & 17,20 & 11,12 & 8,9 & 5,5 & 18,20 & 8,8 & 106 \\
\hline \multirow[t]{4}{*}{13} & F13 & 6,9 & 12,13 & 8,10 & 10,12 & 9,12 & 10,10 & 19,21 & 11,11 & 8,10 & 4,5 & 17,19 & 9,10 & 106,112 \\
\hline & M13 & 7,8 & 8,9 & 9,11 & 9,10 & 10,13 & 11,12 & 20,22 & 11,12 & 9,10 & 4,4 & 18,18 & 10,11 & 106 \\
\hline & S & 6,8 & 9,12 & 8,11 & 10,10 & 10,12 & 10,11 & 19,20 & 11,12 & 10,10 & 4,5 & 17,18 & 10,10 & 106 \\
\hline & S & 7,9 & 8,12 & 8,9 & 9,10 & 9,10 & 10,11 & 19,22 & 11,12 & 8,10 & 4,4 & 18,19 & 10,11 & 106 \\
\hline \multirow[t]{4}{*}{14} & F14 & 6,10 & 8,9 & 8,9 & 10,13 & 14,15 & 10,11 & 16,18 & 10,12 & 10,11 & 4,5 & 12,13 & 10,11 & 106,112 \\
\hline & M14 & 7,9 & 8,8 & 8,8 & 9,11 & 13,15 & 11,11 & 17,19 & 10,11 & 11,11 & 4,4 & 11,12 & 9,10 & 106 \\
\hline & S & 6,9 & 8,9 & 8,9 & 9,13 & 13,14 & 10,11 & 16,17 & 10,12 & 10,11 & 4,4 & 11,12 & 10,10 & 106,112 \\
\hline & S & 6,9 & 8,8 & 8,9 & 9,13 & 13,15 & 11,11 & 17,18 & 10,12 & 10,11 & 4,5 & 11,13 & 9,11 & 106 \\
\hline \multirow[t]{4}{*}{15} & F15 & 6,9 & 8,10 & 8,9 & 10,11 & 10,14 & 12,13 & 15,17 & 11,12 & 8,10 & 5,5 & 8,10 & 8,9 & 106,112 \\
\hline & M15 & 7,10 & 10,12 & 7,8 & 12,13 & 11,13 & 11,12 & 15,16 & 10,11 & 9,10 & 4,4 & 9,11 & 9,10 & 106 \\
\hline & S & 7,9 & 10,10 & 7,8 & 10,12 & 10,13 & 12,13 & 15,15 & 10,12 & 9,10 & 4,5 & 8,9 & 9,9 & 106 \\
\hline & S & 7,9 & 10,12 & 8,8 & 11,12 & 10,13 & 11,12 & 15,17 & 10,11 & 9,10 & 4,5 & 8,11 & 8,9 & 106,112 \\
\hline \multirow[t]{4}{*}{16} & F16 & 7,10 & 7,9 & 8,9 & 10,12 & 12,13 & 12,13 & 18,19 & 9,11 & 11,12 & 4,5 & 13,15 & 11,12 & 106,112 \\
\hline & M16 & 8,11 & 9,10 & 8,8 & 11,13 & 10,11 & 11,12 & 20,21 & 10,11 & 10,11 & 5,5 & 14,16 & 10,11 & 106 \\
\hline & S & 7,11 & 9,9 & 8,8 & 10,13 & 11,12 & 11,12 & 19,20 & 10,11 & 11,11 & 5,5 & 13,14 & 11,11 & 106,112 \\
\hline & S & 8,10 & 7,10 & 8,9 & 10,13 & 11,13 & 12,12 & 18,20 & 10,11 & 10,12 & 4,5 & 13,16 & 11,12 & 106 \\
\hline \multirow[t]{4}{*}{17} & F17 & 8,9 & 11,13 & 7,8 & 12,13 & 15,16 & 11,12 & 20,21 & 9,10 & 7,9 & 4,5 & 16,18 & 11,11 & 106,112 \\
\hline & M17 & 8,8 & 12,12 & 8,9 & 10,12 & 14,16 & 10,11 & 19,20 & 10,11 & 8,10 & 5,5 & 17,18 & 10,11 & 106 \\
\hline & S & 8,9 & 11,12 & 8,9 & 10,13 & 14,16 & 11,10 & 19,20 & 10,11 & 7,8 & 4,5 & 18,18 & 11,11 & 106 \\
\hline & S & 8,9 & 11,12 & 7,9 & 10,12 & 16,16 & 11,10 & 20,20 & 10,11 & 8,9 & 5,5 & 17,18 & 11,11 & 106 \\
\hline \multirow[t]{4}{*}{18} & F18 & 11,13 & 7,8 & 8,10 & 11,12 & 15,16 & 11,12 & 18,19 & 10,11 & 8,9 & 5,5 & 9,10 & 10,11 & 106,112 \\
\hline & M18 & 12,13 & 7,9 & 9,10 & 9,10 & 14,15 & 12,13 & 17,18 & 10,10 & 9,10 & 4,5 & 8,9 & 11,12 & 106 \\
\hline & S & 11,12 & 7,7 & 8,9 & 9,11 & 14,16 & 12,13 & 17,19 & 10,11 & 9,9 & 5,5 & 9,9 & 10,12 & 106 \\
\hline & S & 13,13 & 7,8 & 10,10 & 10,11 & 15,15 & 12,12 & 18,18 & 10,11 & 8,9 & 5,5 & 9,9 & 10,11 & 106 \\
\hline \multirow[t]{4}{*}{19} & F19 & 10,11 & 6,7 & 10,11 & 12,13 & 16,17 & 13,14 & 18,19 & 10,11 & 10,12 & 5,5 & 16,17 & 11,12 & 106,112 \\
\hline & M19 & 11,12 & 7,8 & 9,10 & 12,12 & 17,18 & 12,13 & 19,20 & 11,11 & 11,13 & 4,5 & 17,18 & 9,10 & 106 \\
\hline & S & 10,12 & 7,7 & 9,10 & 12,12 & 16,18 & 12,13 & 19,19 & 11,11 & 12,13 & 5,5 & 17,17 & 10,11 & 106,112 \\
\hline & S & 11,11 & 6,7 & 9,11 & 12,13 & 16,17 & 13,14 & 18,19 & 10,11 & 12,13 & 4,5 & 16,17 & 10,12 & 106,112 \\
\hline \multirow[t]{4}{*}{20} & F20 & 9,10 & 7,8 & 11,12 & 11,12 & 13,14 & 11,12 & 17,18 & 11,12 & 11,12 & 5,5 & 15,16 & 8,9 & 106,112 \\
\hline & M20 & 11,12 & 9,9 & 12,13 & 12,13 & 14,15 & 12,13 & 19,20 & 10,11 & 9,10 & 4,4 & 14,15 & 9,10 & 106 \\
\hline & $S$ & 9,11 & 7,9 & 12,12 & 12,12 & 14,14 & 11,12 & 18,20 & 11,11 & 10,12 & 4,5 & 15,15 & 9,9 & 106 \\
\hline & S & 10,12 & 8,9 & 11,13 & 11,13 & 13,14 & 12,12 & 18,19 & 11,12 & 10,12 & 4,5 & 15,16 & 9,10 & 106 \\
\hline \multirow[t]{4}{*}{21} & $F 21$ & 7,8 & 8,10 & 9,10 & 10,11 & 12,14 & 9,10 & 16,17 & 11,12 & 9,9 & 4,5 & 16,17 & 9,11 & 106,112 \\
\hline & M21 & 7,9 & 9,10 & 10,11 & 10,12 & 11,12 & 11,12 & 15,17 & 12,13 & 8,10 & 4,5 & 16,16 & 10,11 & 106 \\
\hline & S & 7,9 & 10,10 & 9,11 & 10,11 & 12,12 & 10,12 & 15,16 & 11,12 & 8,9 & 4,4 & 16,17 & 11,11 & 106,112 \\
\hline & S & 7,9 & 8,10 & 9,11 & 11,12 & 11,12 & 9,11 & 16,17 & 11,12 & 9,10 & 4,4 & 16,16 & 9,11 & 106,112 \\
\hline \multirow[t]{2}{*}{22} & F22 & 7,9 & 8,10 & 10,11 & 10,11 & 12,14 & 10,11 & 16,17 & 11,11 & 10,10 & 4,5 & 17,17 & 9,10 & 106,112 \\
\hline & M22 & 6,9 & 8,9 & 10,12 & 10,12 & 12,13 & 11,12 & 16,17 & 11,12 & 8,9 & 4,5 & 15,16 & 10,11 & 106 \\
\hline
\end{tabular}


Table 1 Autosomal STR allelic genotype and amelogenin of the 25 full sibling pairs (Continued)

\begin{tabular}{|c|c|c|c|c|c|c|c|c|c|c|c|c|c|c|}
\hline \multirow{2}{*}{$\begin{array}{l}\text { F25 family } \\
\text { volunteers }\end{array}$} & \multicolumn{14}{|c|}{ STR locus } \\
\hline & CODE & TPOX & TH01 & D13S317 & D5S818 & D8S1179 & D16S539 & WA & FES & CSF1PO & F13 & D18S51 & D7S820 & Amelogenin \\
\hline & S & 7,9 & 9,10 & 10,10 & 10,12 & 12,13 & 11,12 & 16,17 & 11,12 & 9,10 & 4,5 & 15,17 & 10,11 & 106,112 \\
\hline & S & 6,7 & 9,10 & 11,12 & 10,12 & 12,12 & 10,11 & 16,17 & 11,11 & 8,10 & 5,5 & 16,17 & 10,11 & 106,112 \\
\hline \multirow[t]{4}{*}{23} & $F 23$ & 7,8 & 8,9 & 10,12 & 12,13 & 12,13 & 11,13 & 15,16 & 11,12 & 9,10 & 4,5 & 15,16 & 10,12 & 106,112 \\
\hline & M23 & 8,9 & 9,10 & 11,13 & 11,13 & 11,13 & 12,14 & 15,15 & 10,11 & 8,10 & 5,5 & 14,15 & 11,12 & 106 \\
\hline & S & 7,8 & 9,10 & 11,12 & 11,12 & 12,13 & 12,13 & 15,16 & 10,11 & 9,10 & 5,5 & 15,16 & 12,12 & 106 \\
\hline & S & 7,8 & 9,10 & 10,11 & 11,13 & 13,13 & 12,13 & 15,15 & 10,11 & 8,10 & 4,5 & 15,15 & 10,11 & 106 \\
\hline \multirow[t]{4}{*}{24} & F24 & 7,8 & 8,10 & 9,11 & 11,12 & 13,14 & 12,13 & 14,17 & 11,12 & 8,10 & 4,5 & 15,16 & 10,12 & 106,112 \\
\hline & M24 & 8,9 & 9,10 & 10,11 & 11,13 & 13,15 & 11,12 & 14,16 & 10,11 & 9,10 & 4,5 & 15,17 & 11,12 & 106 \\
\hline & $S$ & 8,9 & 9,10 & 9,11 & 11,13 & 13,15 & 11,12 & 16,17 & 10,11 & 8,9 & 4,5 & 16,17 & 11,12 & 106,112 \\
\hline & S & 7,9 & 9,10 & 10,11 & 11,13 & 14,15 & 11,13 & 14,17 & 10,12 & 8,9 & 4,5 & 16,17 & 10,11 & 106,112 \\
\hline \multirow[t]{4}{*}{25} & $F 25$ & 7,9 & 9,9 & 11,12 & 11,13 & 12,14 & 12,13 & 14,17 & 10,11 & 9,11 & 4,5 & 15,17 & 10,12 & 106,112 \\
\hline & M25 & 8,9 & 9,10 & 11,13 & 11,12 & 12,12 & 13,13 & 16,17 & 10,12 & 9,12 & 4,5 & 16,18 & 11,12 & 106 \\
\hline & S & 8,9 & 9,10 & 11,13 & 11,12 & 12,12 & 12,13 & 14,16 & 10,11 & 9,11 & 4,5 & 15,16 & 10,11 & 106,112 \\
\hline & S & 8,9 & 9,10 & 11,11 & 11,12 & 12,12 & 12,13 & 17,17 & 11,12 & 9,11 & 4,5 & 16,17 & 12,12 & 106,112 \\
\hline
\end{tabular}

permitted dissemination and publication of results. Privacy and volunteers' confidentiality were adhered too.

\section{Sample preparation}

A total of 100 blood sample extracted from peripheral blood system was stored in EDTA vacutainer blood collection tube, labeled with letters $\mathrm{f}, \mathrm{m}$, and $\mathrm{s}$ to denote sample from father, mother, and sibling respectively. Letters differentiated families in chronological order (Table 1).

\section{DNA extraction}

The DNA extraction process of 100 samples (25 sibling pairs included) followed the described DNAzol Organic method protocol (Chomczynski et al. 1997; Chen et al. 2010; McClintock 2014). Isolated DNA pellet was resuspended in a $50 \mu \mathrm{l}$ of distilled water to final volume.

\section{DNA PCR amplification}

DNA amplification process by PCR-STR (PowerPlex ${ }^{\circ} 21$ Systems, Promega, USA) targeted a specific region of DNA to create number of copies from isolated DNA. Amplification of all 80 samples used 12 autosomal STR loci (CSF1PO, F13B, FES, TH01, TPOX, vWA, D5S818, D7S820, D8S1179, D13S317, D16S539, and D18S51) and a sex typing amelogenin gene locus. PCR system was on MicroAmp 88 well plate in the GeneAmp ${ }^{\circ}$ PCR System Bio-Rad T100TM thermal cycler at $2 \mathrm{~h}$ and $7 \mathrm{~min}$. The PCR setting was as follows: $96{ }^{\circ} \mathrm{C}$ for $2 \mathrm{~min}$, then $94{ }^{\circ} \mathrm{C}$ for $1 \mathrm{~min}, 64{ }^{\circ} \mathrm{C}$ for $1 \mathrm{~min}, 70{ }^{\circ} \mathrm{C}$ for $1.5^{\circ} \mathrm{min}$, for $10 \mathrm{cy}$ cles, then $90{ }^{\circ} \mathrm{C}$ for $1 \mathrm{~min}, 64{ }^{\circ} \mathrm{C}$ for $1 \mathrm{~min}, 70{ }^{\circ} \mathrm{C}$ for 1.5 min, for 30 cycles. DNA polymerized template continued with typing while stored at $4{ }^{\circ} \mathrm{C}$, protocol according to Lorenz (2012).

\section{Electrophoretic reaction}

The resulted PCR products were electrophoresed on Bio-Rad Mini-PROTEAN ${ }^{\circ}$ vertical electrophoresis (Life Science Group, United Kingdom) under 6\% polyacrylamide gel (PAGE) with Silver Nitrate.

\section{Allelic frequency and matching}

Profiled DNA was read according to the allele genotype of each STR loci (12 STR) and the sex gene (Amel). The information was then tabled to show the allele genotype of every STR loci to all the 100 volunteers (refer to Table 1). Allele genotype was then matched among sibling (after parents' comparison) and converted into allelic frequencies to present the number of times allele shared on two alleles, one allele, and zero allele-sharing category (Fig. 2). The three categories were then plotted according to the shared allele on every STR loci then an aggregation of the two, one, and zero allele sharing was figured to the percentage (refer to Fig. 3). Finally, analysis and contribution discussed based on sharing frequencies on each STR used to establish STR of choice for sibship among Madurese.

\section{Description of the chosen population}

Madurese is the second largest ethnic group together with Sundanese and Malay after Javanese. The group originated in Madura Island located on the northeast of East Java. The Madura Island experience unique features of socio-cultural diversity, geographical and boundary isolation together with climatic and environmental 


\section{TH01}

TPOX

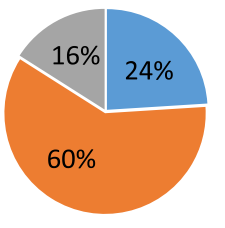

$$
\begin{aligned}
& \square \text { Allele sharing } \\
& \square 1 \text { allele sharing } \\
& \square 0 \text { allele sharing }
\end{aligned}
$$

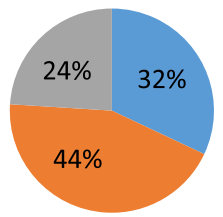

$$
\begin{aligned}
& -2 \text { Allele sharing } \\
& -1 \text { allele sharing } \\
& \square \text { allele sharing }
\end{aligned}
$$

D13S317

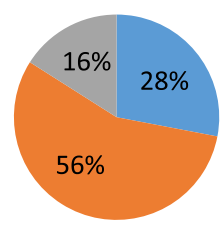

- 2 Allele sharing

1 allele sharing

0 allele sharing

\section{D16S539}

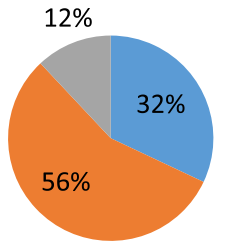

- 2 Allele sharing

1 allele sharing

0 allele sharing

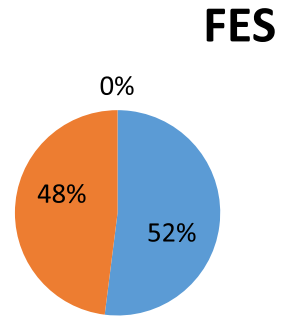

$$
\begin{array}{r}
-2 \text { Allele sharing } \\
\square 1 \text { allele sharing } \\
\square \text { allele sharing }
\end{array}
$$

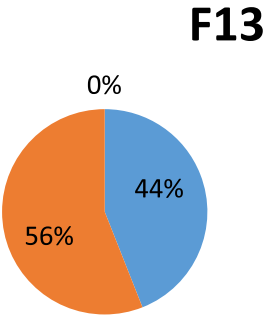

$\square$ Allele sharing
$\square 1$ allele sharing
$\square 0$ allele sharing

Fig. 2 Percentage allele sharing of 25 full sibling pairs on 12 STR loci

condition which reflect other many islands. The group forms the 3000 bio-diversified ethnicities of the vast archipelago transcontinental country, Indonesia. The country is on 17,000 islands from Southeast Asia to Australia along the equator between the Pacific and Indian Ocean with average temperature at $22{ }^{\circ} \mathrm{C}$ to $32{ }^{\circ} \mathrm{C}$. The tropical country, Indonesia, inhabit the fourth largest population in the world.

\section{Results and discussion}

According to Wenk, Traver, and Chiafari (1996), allele sharing in the determination of sibling is of use to strongly establish a relationship when both two alleles are involved. Commenting on practice, it is even further advised that, if possible each community with their respective laboratory should establish their own STR loci that would attain a highly discriminative relation of its individual, one being through sibship relation (Tzeng et al. 2000) and for gender determination, for example, STR5 system by Loci (vWA, TH01, D13S317, D18S51, and D21S11) and amelogenin genes in cell-free fetal DNA (Sosiawan et al. 2018). STR12 loci system analysis is one of the primary technologies for genetic human identification (forensic science, paternity, and some anthropological studies) with good validity, accuracy specificity, and sensitivity (Krenke et al. 2005). However, nowadays, STR12 loci system has been increased to STR24 loci system with better accuracy result (Lu et al. 2012). In Indonesia, STR12 loci system has been established and used for a long time. Meanwhile, STR24 loci system is quite a new system and unavailable in Indonesia, that is the reason this study is using STR12 loci system. Reflecting the principles to our study, efforts are marked as to other world community in finding out the appropriate STR12 loci of choice in forensic practice and database establishment among Madurese of Indonesia.

Analyzing on sibling relation by autosomal and sex gene loci, amel successfully verified the sex/gender of all the 25 family members as to recruited individuality (Table 1). Autosomal STR loci typing present the allelic genotype of the 25 pairs of full siblings in relation to their parents, percentage of sharing and the frequencies of the 12 STR loci (refer Table 1). From 300 observations (25 pairs of full-sibling $\times 12$ loci) of genotyped STR allele, of allele sharing, has found 4 STR loci: FES, CSF1PO, F13, D8S1179 with high 


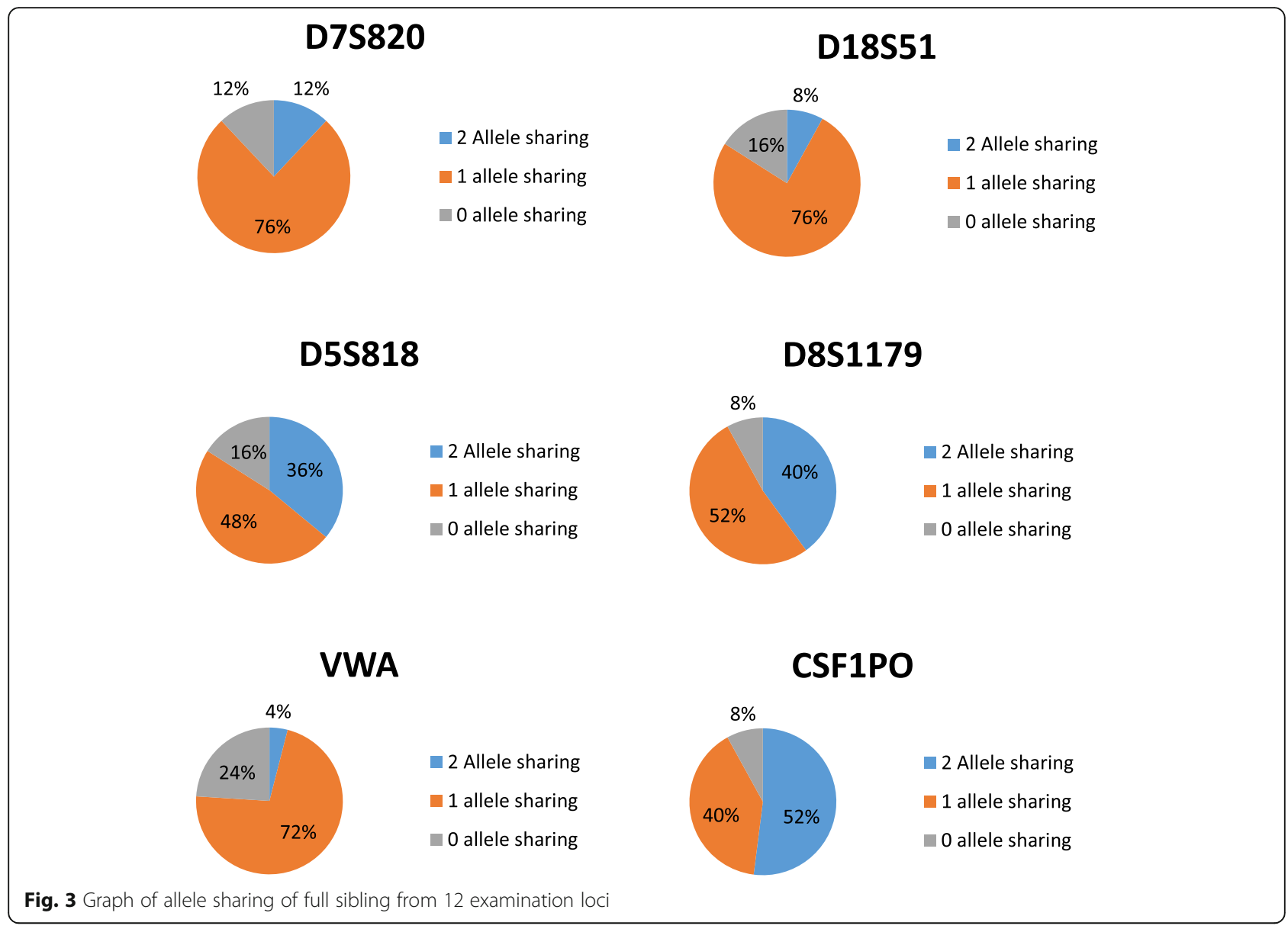

shared allelic frequency in two alleles sharing among twelve STR loci by $52 \%, 52 \%, 44 \%$, and $40 \%$ respectively. As for the four main loci of full sibling with one allele sharing, i.e, D7S820, D18S51, vWA, and THO1 have a sequence of percentages from large to small as follows: $76 \%, 76 \%, 72 \%$, and $60 \%$ respectively. Furthermore, STR locus VWA expressed null shared allele in 24 allele sharing category. Likewise, F13 and FES both typed null allele in zero allele sharing category among these full sibling (Fig. 2).

The 300 full sibling observations, combined average of shared allele on two, one, and zero allele sharing in full sibling by 12 STR loci is shown in Fig. 3. Presentation of the three allele sharing groups of zero allele sharing, one allele sharing, and two allele sharing demonstrate that one allele were shared the most with highest frequency at 57\% throughout 12 STR loci. Two alleles sharing followed the second by $33.33 \%$, zero allele came the last at $12.66 \%$ shared allele (Fig. 3). The established trend is gradual from two alleles sharing to zero allele sharing. The demonstration present useful finding in use to attend sibling cases as. This is in agreement with the conclusion that one allele sharing is of great evidence in establishing sibship (Wenk, Traver, and Chiafari 1996). Also, the trend proves the usefulness of determining and typing sibship with large number of STR loci to minimize the chance of rejection while maximizing accuracy, the contrary can lead to typing zero or two allele sharing at high frequency hence reduced precision confidence of sibling establishment (Reid et al. 2004; Maeda et al. 2015). Presence of shared zero allele is an implication to the fact that not always full sibling will be found to share allele as compared to the accuracy of kinship analysis. This is by Mendelian theoretical fact of inheritance (Reid et al. 2008).

Allele frequency from allele sharing in this study were 247 FES, F13, D8S1179, CSF1PO, D16S539, D7S820, and $248 \mathrm{THO}$, respectively, $100 \%, 100 \%$, 92\%, 92\%, 88\%, 88\%, 249 and $84 \%$ (Table 2). This result is slightly different from the findings of Hameed et al. (2015), D16S539, THO1, vWA, D5S818, D8S1179, D3S1357, CSF1PO, respectively, 88\%, 81\%, 80\%, 77\%, $74 \%, 72 \%$, and $71 \%$. From the sequence to 7 loci from the 2 studies there are 4 similar loci that can be used as references, namely, D8S1179, CSF1PO, D16S539, and THO1. 
Table 2 Allele sequence sharing from highest to lowest locus

\begin{tabular}{llllll}
\hline & LOCl & 2 allele sharing & 1 allele sharing & 2 allele + 1 allele sharing & 0 allele sharing \\
\hline 1 & FES & 52 & 48 & 100 & 0 \\
2 & F13 & 44 & 56 & 100 & 0 \\
3 & D8S1179 & 40 & 52 & 92 & 8 \\
4 & CSF1PO & 52 & 40 & 52 & 8 \\
5 & D16S539 & 32 & 56 & 88 & 12 \\
6 & D7S820 & 12 & 76 & 88 & 12 \\
7 & TH01 & 24 & 60 & 84 & 16 \\
8 & D13S317 & 28 & 56 & 84 & 16 \\
9 & D5S818 & 36 & 48 & 84 & 16 \\
10 & D18S51 & 8 & 76 & 84 & 16 \\
11 & TPOX & 32 & 44 & 76 & 24 \\
12 & WWA & 4 & 72 & 87.33333333 & 16 \\
Average percentage & & 30.33333 & 57 & & 12.66667
\end{tabular}

Table 3 Allele sharing and allele frequency full sibling in 12 loci

\begin{tabular}{|c|c|c|}
\hline Family & 12 STR loci allele sharing & Allele frequency (\%) \\
\hline 1 & 8 & 66.666666667 \\
\hline 2 & 12 & 100 \\
\hline 3 & 10 & 83.33333333 \\
\hline 4 & 10 & 83.33333333 \\
\hline 5 & 12 & 100 \\
\hline 6 & 8 & 66.666666667 \\
\hline 7 & 11 & 91.666666667 \\
\hline 8 & 12 & 100 \\
\hline 9 & 11 & 91.66666667 \\
\hline 10 & 10 & 83.33333333 \\
\hline 11 & 10 & 83.33333333 \\
\hline 12 & 10 & 83.33333333 \\
\hline 13 & 11 & 91.666666667 \\
\hline 14 & 11 & 91.666666667 \\
\hline 15 & 12 & 100 \\
\hline 16 & 9 & 75 \\
\hline 17 & 12 & 100 \\
\hline 18 & 8 & 66.666666667 \\
\hline 19 & 11 & 91.666666667 \\
\hline 20 & 9 & 75 \\
\hline 21 & 11 & 91.66666667 \\
\hline 22 & 11 & 91.666666667 \\
\hline 23 & 11 & 91.666666667 \\
\hline 24 & 12 & 100 \\
\hline 25 & 11 & 91.666666667 \\
\hline Average percentage & 10.52 & 87.666666667 \\
\hline
\end{tabular}

Table 3 shows that the mean locus obtained from the examination of 12 full locus sibling is 10.52 loci (both 2 allele sharing and 1 allele sharing), with an average allele frequency of $87.33 \%$. This value is still below the standard full sibling examination which has been set by USCIS (US Citizenship and Immigration Services), at 90\% (2018). However, the USCIS standard value cannot be used as the basis for excluding full sibling DNA examination results. Other DNA examinations are needed as an additional examination (USCIS, 2018)

Execution of this study in assessing allele-sharing extent and establishment of usability of established STR loci in sibship among Madurese paid consideration to prior recommended STR. The consideration aligned the locally tested and recommended loci for the general population discrimination among Madurese, Indonesia, and other global population for continuity of population genetics research work. For example, Kido et al. (2003) established the usefulness of vWA, TH01, TPOX, and F13A01 (highly polymorphic and useful STR in forensic and paternity examination). The report recommended to be chosen when assessing allelic frequency among Japanese, Bangladeshis, and Indonesians, though some variability emerges on $\mathrm{F} 13 \mathrm{~B}$ with high frequency at allele $5 \mathrm{com}$ pared to allele 6 on F13A of the report. The study also considered 15 STR analyzed among Indonesians and Bangladeshis with exception of FES and F13B (Dobashi et al. 2005) whereby all agreed with Hardy-Weinberg equilibrium to be used in the two populations with the highest discrimination at D21S11 among Indonesians as to D18S51 among Southern Egyptians (Omran, Rutty, and Jobling 2009). However, the Indonesian 


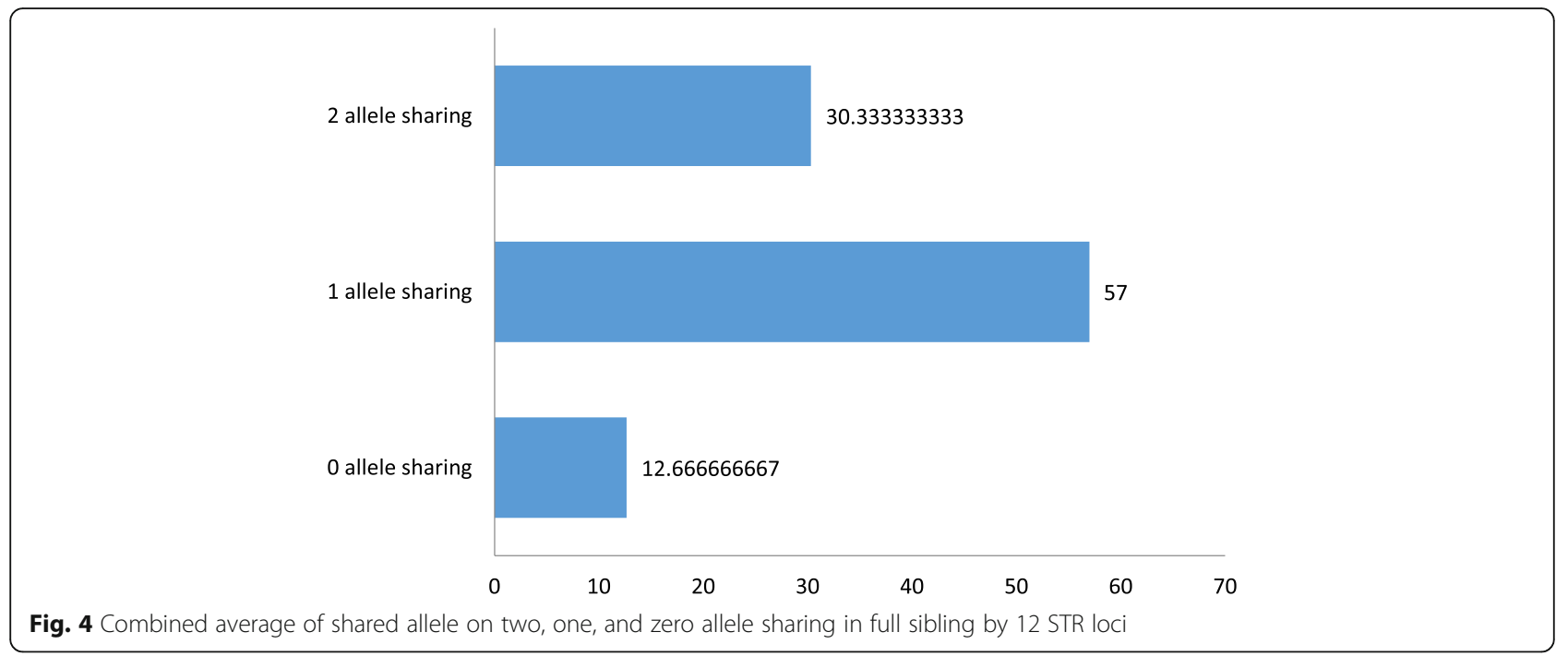

population is highly dispersed on CODIS STR though specific and different compared to other Asians (Untoro et al. 2009). The specificity necessitates the use of verified STR of choice to attain the inquiry. This is similar to a study by Prastowo et al. (2018) on Madurese over 13 CODIS against two ethnicities. The report acknowledges peculiarity of the group to emphasized narrowed studies for the specificity of STR loci use among Madurese in contribution to Indonesians population database of reference. Of the 12 assessed STR loci in assessing sibling relationship among Madurese with consideration of the established population genetics, this study therefore recommends the use of FES, F13, D8S1179, and CSF1PO, and the four STR loci showed evidence to have high discrimination among individuals with maximum efficiency when typing for sibling relationship. Confident of recommendation is also supported in the finding of high-frequency typing of the shared allele on the two allele sharing compared to one allele sharing (Reid et al. 2004) (Fig. 4)

\section{Conclusion}

When assessing for sibling relationship, careful consideration has to be on the localized confirmed STR of use to minimize false-positive typing as not always full sibling will present high frequency of the two sharing allele. For that, every community is supposed to establish the STR loci of choice that better type the gene of her population. The finding of this study therefore recommends the use of FES, F13, D8S1179, and CSF1 when typing sibling among Madurese, though the more STR loci, the more the mismatch chances are reduced. These four STR loci will also help Indonesia when considering to extending its DNA database to sibling relation.

\section{Abbreviations}

CODIS: Combined DNA Index System; DNA: Deoxyribonucleic acid; PCR: Polymerase chain reactions; STRs: Short tandem repeats

\section{Acknowledgements}

The authors would like to thank the Indonesia Ministry of Research and High Education for the funding, community of Madura and all volunteered families, Universitas Airlangga (UNAIR), Faculty of Medicine, Faculty Dental Medicine, Postgraduate School (Forensic Science Program) and Human Genetic and Forensic Laboratory of the Institute for Tropical Diseases, Universitas Airlangga, Surabaya, Indonesia.

\section{Authors' contributions}

AY acquired the funding. AS and AY were responsible for the conception and design of the study. AHF contributed to the sample collection. AHF, AS, $A Y$, and SMMN helped in the laboratory experimentation. AY and AS contributed to the data reading and interpretation. SMMN and AHF analyzed the data. SMMN wrote the manuscript. AS, AY, SMMN, and AHF revised the manuscript critically for important intellectual content. All authors read and approved the final manuscript.

\section{Authors' information}

Agung Sosiawan, PhD, DDS, MSc (Health) is a Forensic Science expert in Dental Genetics, is a Lecturer and Vice Dean at the Faculty of Dental Medicine, and is a Researcher in the Research Group of the Human Genetic Laboratory of Universitas Airlangga Surabaya, Indonesia.

Ahmad Yudianto, PhD, MMed, MD is Forensic Science and Medico-legal Specialist is a Lecturer and Head of the Forensic Science Master Program at the University of Airlangga since 2010/2011, and is a Specialist Doctor's Education Program since 2015. Forensic, Medico-legal, and Expert Witness since 2007 and Researcher in the Research Group of the Human Genetic Laboratory of Universitas Airlangga Surabaya, Indonesia.

Abdul Hadi Furgoni, MFS, BSCN, PhD student in Medical Science at School of Medicine, and a Research Assistant in the Research group of the Human Genetic Laboratory of Universitas Airlangga Surabaya, Indonesia.

Simon Martin Manyanza Nzilibili, RN, BSCN is a Nursing Placement and Capacity Building Officer at Ministry of Health, Tanzania, is a Masters student in Forensic Science at the Post-graduate School, and is a Volunteer Research Assistant in the Research Group of the Human Genetic Laboratory of the Airlangga University, Surabaya, Indonesia.

Indah Nuraini, MFS, BSc Biology. Currently, she is working with the Human Genetic Laboratory as in-charge and technician of the laboratory. She is a member of the Human Genetic Study group for more than 16 years and been involved in a number of studies conducted on human genetic and forensic in the laboratory. 


\section{Funding}

This research has been funded by Penelitian Unggulan Pengguruan Tinggi Negeri (PUPTN), Ministry of Research and Higher Education-Indonesia with award number 200/UN3.14/LT/2018 and Grant Recipient was Ahmad Yudianto, Ph.D.

\section{Availability of data and materials}

All the materials and data collected during study experimentation will be shared upon request.

\section{Ethics approval and consent to participate}

This research study got ethical approval through a clearance number 256/ HRECC.FODM/IV/2018 by the Health Research Ethical Clearance Commission of the Faculty of Dental medicine, Universitas Airlangga.

\section{Consent for publication}

Participants involved gave consent for the study for knowledge sharing and publication.

\section{Competing interests}

The authors declare that they have no competing interest.

\section{Author details}

${ }^{1}$ Faculty of Dental Medicine, Universitas Airlangga, Jl. Mayjend. Prof. Dr. Moestopo 47, Surabaya 60132, Indonesia. ${ }^{2}$ Department of Forensic and Medico-legal, Faculty of Medicine, Airlangga University, Surabaya, Indonesia. ${ }^{3}$ Forensic Science Program, Post Graduate School, Universitas Airlangga, 4-6 Airlangga Rd, Surabaya 60286, Indonesia. ${ }^{4}$ Human Genetic and Forensic Laboratory, Institute of Tropical Disease, Universitas Airlangga, Surabaya, Indonesia. ${ }^{5}$ Medical Science Program, Faculty of Medicine, Universitas Airlangga, Surabaya, Indonesia. ${ }^{6}$ Ministry of Health, Community Development, Gender Elderly and Children, Dodoma, Tanzania.

Received: 13 December 2018 Accepted: 20 June 2019

Published online: 13 July 2019

\section{References}

Agrawal S, Khan F (2005) Reconstructing recent human phylogenies with forensic STR loci: a statistical approach. BMC Genetics. https://doi.org/10.1186/14712156-6-47

Butler JM, Hill CR (2012) Biology and genetics of new autosomal STR loci useful for forensic DNA Analysis

Butler JM (2006) Genetics and genomics of core STR loci used in human identity testing *. J Forensic Sci:1-48

Butler JM (2015) The future of forensic DNA analysis. Philos Trans R Soc Lond B Biol Sci 370(1674). https://doi.org/10.1098/rstb.2014.0252

Chen H, Rangasamy M, Tan SY, Wang H, Siegfried BD (2010) Evaluation of five methods for total DNA extraction from western corn rootworm beetles. PLoS ONE 5(8). https://doi.org/10.1371/journal.pone.0011963

Chomczynski P, Mackey K, Drews R, Wilfinger W (1997) NAzol: a reagent for the rapid isolation of genomic DNA. BioTechniques 22(3):550-553

Dobashi Y, Kido A, Fujitani N, Hara M, Susukida R, Oya M (2005) Announcement of population data STR data for the AmpFLSTR identifiler loci in Bangladeshi and Indonesian populations 7, pp 222-226. https://doi.org/10.1016/j. legalmed.2005.04.001

Hameed IH, Ommerb JA, Murad AF, Mohammed GJ (2015) Allele frequency data of 21 autosomal short tandem repeat loci in Mesan and Basra provinces in South Iraq. Egypt J Forensic Sci 5(4):150-156

Hares DR (2012) Expanding the CODIS core loci in the United States dear. Forensic Science International: Genetics 6:e52-e54. https://doi.org/10.1016/j. fsigen.2015.03.006

Hares DR (2015) Selection and implementation of expanded CODIS core loci in the United States. Forensic Science International: Genetics 17:33-34. https:// doi.org/10.1016/j.fsigen.2015.03.006

Kido, A, R Susukida, M Oya, N Fujitani, H Kimura, and M Hara. 2003. Allele frequency distributions of four STR loci WWA, TH01, TPOX and F13A01 in three Asian populations (Japanese, Bangladeshis and Indonesians )" 1239 $105-8$

Krenke BE, Viculis L, Richard ML, Prinz M, Milne SC, Ladd C, Gross AM, Gornall T, Frappier JR, Eisenberg AJ, Barna C, Aranda XG, Adamowicz MS, Budowle B
(2005) Validation of a male-specific, 12-locus fluorescent short tandem repeat (STR) multiplex. Forensic Sci Int. 148(1):1-14

Lorenz TC (2012) Polymerase chain reaction: basic protocol plus troubleshooting and optimization strategies. J Visualized Exp 63:1-15. https://doi.org/10.3791/ 3998

Lu D, Liu Q, Wu W, Zhao H (2012) Mutation analysis of 24 short tandem repeats in Chinese Han population. Int J Legal Med 126(2):331-335

Maeda K, Murakami C, Irie W, Sasaki C, Oishi M, Nakamaru N, Nakamura S, Kurihara K (2015) The case of 2 siblings that identified not only by DNA profiling. Forensic Science International: Genetics Supplement Series 5:e555-e556. https://doi.org/ 10.1016/j.fsigss.2015.09.219

McClintock, J. Thomas. 2014. Forensic analysis of biological evidence: a laboratory guide for serological and DNA typing. https://books.google.com/books?id= 4 HLNBQAAQBAJ\&pgis=1.

Omran GA, Rutty GN, Jobling MA (2009) Genetic variation of 15 autosomal STR loci in upper (Southern) Egyptians. Forensic Science International: Genetics 3(2). https://doi.org/10.1016/j.fsigen.2008.05.007

Prastowo W, Lyrawati D, Andarini S, Mintaroem K (2018) Allele frequencies of STR CODIS 13 of Madura Ethnic from Bangkalan and Probolinggo. Res J Life Sci 5(2):116-120. https://doi.org/10.21776/ub.rjls.2018.005.02.5

Reid TM, Baird ML, Reid JP, Lee SC, Lee RF (2008) Use of sibling pairs to determine the familial searching efficiency of forensic databases. Forensic Science International: Genetics 2(4):340-342. https://doi.org/10.1016/j.fsigen. 2008.04.008

Reid TM, Wolf C a, Kraemer CM, Lee SC, Baird ML, Lee RF (2004) Specificity of sibship determination using the $A B I$ identifiler multiplex system. Journal of Forensic Sciences 49(6):1262-1264

Sosiawan A, Raharjo D, Nuraini I, Kartikasari N, Nugraha AP, Ari MDA (2018) Detection of short-tandem repeats at 5 loci and amelogenin with cell-free fetal DNA as a specimen in the development of prenatal paternity diagnostic tests. Egypt J Forensic Sci 8:15 DOI 101186/s41935-018-004-9

Tzeng CH, Lyou JY, Chen YR, Hu HY, Lin JS, Wang SY (2000) P a r e n t a g e t e s t i n G. Transfusion 40(July):840-845

United State Department of Homeland Security, 2018. Policy memorandum (PM) amends U.S. Citizenship and Immigration Services' (USCIS) policy on DNA evidence of sibling relationships and revises the Adjudicator's Field Manual (AFM), Chapter 21.9(c). April 17, 2018.

Untoro E, Atmadja DS, Pu CE, Wu FC (2009) Allele Frequency of CODIS 13 in Indonesian Population. Legal Medicine 11(SUPPL. 1):S203-S205. https://doi. org/10.1016/j.legalmed.2009.01.007

Wenk RE, Traver M, Chiafari FA (1996) Determination of sibship in any two persons. transfusion 36(3):259-262. https://doi.org/10.1046/j.1537-2995.1996. 36396182146.x

\section{Publisher's Note}

Springer Nature remains neutral with regard to jurisdictional claims in published maps and institutional affiliations.

\section{Submit your manuscript to a SpringerOpen ${ }^{\circ}$ journal and benefit from:}

- Convenient online submission

- Rigorous peer review

- Open access: articles freely available online

- High visibility within the field

- Retaining the copyright to your article

Submit your next manuscript at $>$ springeropen.com 